\title{
The development of Empirica .... and its anchorman Fritz Breuss
}

\section{Christoph Badelt ${ }^{1} \cdot$ Karl W. Steininger ${ }^{2} \cdot$ Rudolf Winter-Ebmer $^{3}$}

Published online: 10 April 2021

(C) The Author(s), under exclusive licence to Springer Science+Business Media, LLC, part of Springer Nature 2021

Evidently, a journal is shaped by the fruitful interaction of its readers, authors, reviewers, editorial board and editors. Yet, for Empirica there is hardly anybody who has guided and shaped it more since its foundation than Fritz Breuss, who served as its Managing Editor for the last dozen of years. When coming into office in early 2009 his stewardship transformed Empirica to the "Journal of European Economics", reflected in a new external appearance, but more importantly in a very fruitful internal development, towards a core forum for analyzing and discussing the very European economic issues. The data of the last years given in Tables 1 and 2 may serve as an indicator for this apparent development. The Journal Impact Factor has more than tripled, and so did the number of downloads.

As issuing organisations of Empirica it has always been insightful to get to know some of the details behind, as it may be for you as readers: While the annual number of submissions in 2008 had been 21, after five years it had risen to 95, passed 140 in 2018, and last year was at 173 (2020). In total, Managing Editor Fritz Breuss has handled 1110 submitted manuscripts (2009-2020), of which 331 were ultimately published (acceptance rate 30\%), 63 withdrawn and 280 transferred. The average period of submission to first decision has declined to 62 days (2020), the average timeline until acceptance is 255 days (2020). The managing editor relied on associate editors and an editorial board, appointed in 2009, with a composition changed in 2014 and repeatedly thereafter. The current compositions are available at the journal's front page, both boards are identically sized in 2021 as they were in 2009.

Fritz Breuss was appointed as Managing Editor in 2009-unanimously by both issuing organizations, a confidence that he has truly more than confirmed by his excellent and highly recognized service during his managing period. For his first two years in office he even served twofold, also as president of the Austrian

Karl W. Steininger

karl.steininger@uni-graz.at

1 Austrian Institute of Economic Research, Wien, Austria

2 University of Graz, Graz, Austria

3 University of Linz, Linz, Austria 
Table 1 Development of Journal Impact Factor of Empirica

\begin{tabular}{ll}
\hline Year & Journal \\
& $\begin{array}{l}\text { Impact } \\
\text { Factor }\end{array}$ \\
\hline 2012 & 0.250 \\
2013 & 0.160 \\
2014 & 0.462 \\
2015 & 0.359 \\
2016 & 0.658 \\
2017 & 0.706 \\
2018 & 0.836 \\
2019 & 0.890 \\
\hline
\end{tabular}

Table 2 Downloads of journal Empirica

\begin{tabular}{ll}
\hline Year & Downloads \\
\hline 2013 & 24013 \\
2014 & 22812 \\
2015 & 26203 \\
2016 & 32310 \\
2017 & 45493 \\
2018 & 44778 \\
2019 & 56243 \\
2020 & 72694 \\
\hline
\end{tabular}

Economic Association. He always assumed responsibility to organize top-relevant issues. As representatives of these organisations, as well as in our role as authors, reviewers and members of the editorial board of the journal, we always had his collaboration in the best possible and beneficial way.

All colleagues who have personally worked with Fritz Breuss are witnesses of his extraordinary character: He combines a thorough knowledge of international economics, the key features of the European Union and the European economy with a tremendous personal engagement not only for the journal he was managing but also for the ideas of Europe as a political concept. Against this background it was him who worked successfully for the "emancipation" of Empirica-from a nice Austrian journal to a true international location of scholarly work. Moreover, he has always been a friendly and supportive colleague, which is why all fellows who have cooperated with him in his Empirica role will stay his heartily committed colleagues, often even friends.

We thank Fritz Breuss for being (at) the heart of Empirica, even more so for this extensive time, and for shaping it the way he did! Empirica could not have flourished better. 
As in mid-2020 Fritz Breuss has asked us to set up a process for transferring the function of Managing Editor to the next generation, we now wish the team around Harald Oberhofer, who is serving as Editor-in-Chief since early 2021 a fruitful development, much for the benefit of all the readership!

Christoph Badelt, Karl W. Steininger and Rudolf Winter-Ebmer

Publisher's Note Springer Nature remains neutral with regard to jurisdictional claims in published maps and institutional affiliations. 